\title{
Electron Spin Resonance Spectral Characterization and DNA Binding Studies of Metal Complexes with Heterocyclic Ligands Derived from 4 -Aminoantipyrine and 5-Chlorosalicylaldehyde / 3-Ethoxysalicylaldehyde
}

\author{
B. ANUPAMA ${ }^{\mathrm{a}}$, CH. VENKATA RAMANA REDDY ${ }^{\mathrm{b}}$ and C. GYANA KUMARI ${ }^{\mathrm{a}^{*}}$ \\ ${ }^{\text {a } D e p a r t m e n t ~ o f ~ C h e m i s t r y, ~ O s m a n i a ~ U n i v e r s i t y, ~ H y d e r a b a d ~-500007, ~ I n d i a ~}$ \\ ${ }^{\mathrm{b}}$ Department of Chemistry, JNTUHCEH, JNT University, Hyderabad-500085, India \\ anupama_gudi@yahoo.co.in
}

Received 26 September 2012 / Accepted 19 October 2012

\begin{abstract}
Transition metal complexes of $\mathrm{Cu}(\mathrm{II}), \mathrm{Ni}(\mathrm{II})$ and $\mathrm{Co}(\mathrm{II})$ have been synthesized involving the heterocyclic Schiff bases, 2,3-dimethyl-1-phenyl-4-(5-chloro-2-hydroxybenzylideneamino)-pyrazol-5one (5-CISALAAP), $\mathrm{L}_{1}$ and 2,3-dimethyl-1-phenyl-4-(3-ethoxy-2-hydroxy benzylideneamino)pyrazol-5-one (3-OEtSALAAP), $\mathrm{L}_{2}$ derived from 4-aminoantipyrine and 5-chlorosalicylaldehyde/ 3ethoxysalicylaldehyde respectively. These Schiff bases act as tridentate ligands which coordinate through the azomethine nitrogen, phenolic oxygen and carbonyl of antipyrine ring. The ESR Spectra of $\mathrm{Cu}(\mathrm{II})$ complexes were recorded at room temperature in the polycrystalline state. These complexes exhibited well resolved anisotropic signals in the parallel and perpendicular regions. The trend, $\mathrm{g}_{\Pi}>\mathrm{g}_{\perp}$ $>2.0023$ observed for the complexes indicate that unpaired electron is localised in $\mathrm{d}_{\mathrm{x}-\mathrm{y}}{ }^{2}$ orbital of the $\mathrm{Cu}(\mathrm{II})$ ion. Hence a distorted octahedral geometry is proposed for the complexes. The value of exchange interaction was estimated from the equation, $G=\left(g_{\Pi}-2\right) /\left(g_{\perp}-2\right)$. The complexes showed $G$ values $<4$ indicating the exchange interaction in complexes. Binding of these complexes with calf thymus DNA(CT DNA) was studied by spectroscopic methods and their binding constants were evaluated.
\end{abstract}

Keywords: Heterocyclic Schiff bases, DNA Binding Studies, Synthesis, 4 -Aminoantipyrine

\section{Introduction}

The heterocyclic Schiff base ligands and their transition metal complexes are known to possess numerous biological and other applications ${ }^{1-3}$. The synthesis, characterization and antibacterial studies of transition metal complexes involving 2,3-dimethyl-1-phenyl-4-(5-chloro-2-hydroxybenzylideneamino)-pyrazol-5-one (5-ClSALAAP), $\mathrm{L}_{1}$ and 2,3-dimethyl-1-phenyl-4-(3-ethoxy-2hydroxy benzylideneamino)-pyrazol-5-one (3-OEtSALAAP), $\mathrm{L}_{2}$ were reported in our earlier paper ${ }^{4}$. The present paper reports the ESR spectra and DNA binding study of these complexes.

\section{Experimental}

The synthesis and characterization of the ligands $\mathrm{L}_{1}$ and $\mathrm{L}_{2}$ and their $\mathrm{Cu}(\mathrm{II}), \mathrm{Ni}(\mathrm{II})$ and $\mathrm{Co}(\mathrm{II})$ metal complexes were same as those reported ${ }^{4}$ in our earlier study. 


\section{ESR spectra}

The ESR spectra of the Cu(II) complexes were recorded on Jeol, JES -FA 200 ESR spectrometer at room temperature.

\section{DNA Binding studies}

Concentrated CT -DNA stock solution was prepared in $5 \mathrm{mM}$ Tris $-\mathrm{HCl} / 50 \mathrm{mM} \mathrm{NaCl}$ in water at $\mathrm{pH}-7.5$ and the concentration of DNA solution was determined by UV absorbance at $260 \mathrm{~nm}$. The molar absorption coefficient ${ }^{5}$ was taken as $6600 \mathrm{M}^{-1} \mathrm{~cm}^{-1}$. Solution of CTDNA in $5 \mathrm{mM}$ Tris $-\mathrm{HCl} / 50 \mathrm{mM} \mathrm{NaCl}(\mathrm{pH}=7.5)$ gave a ratio of $\mathrm{UV}$ absorption at $260 \mathrm{~nm}$ and $280 \mathrm{~nm} \mathrm{~A}_{260} / \mathrm{A}_{280}$ of ca 1.8-1.9, indicating that the DNA was sufficiently free of protein ${ }^{6}$.

All stock solutions were stored at $4{ }^{\circ} \mathrm{C}$ and were used within one week. Absorption spectra were recorded on Elico SL 159 UV-Visible spectrophotometer using $1 \mathrm{~cm}$ quartz microcuvettes. Absorption titrations were performed by keeping the concentration of the complex constant $(16 \mu \mathrm{M})$ and by varying the concentration of CT-DNA from $0-140 \mu \mathrm{M}$. For the complexes, the binding constants $\left(\mathrm{K}_{\mathrm{b}}\right)$, have been determined from the spectroscopic titration data using the following equation ${ }^{7,8}$.

$$
[D N A] /\left(\varepsilon_{\mathrm{a}}-\varepsilon_{\mathrm{f}}\right)=[\mathrm{DNA}] /\left(\varepsilon_{\mathrm{b}}-\varepsilon_{\mathrm{f}}\right)+1 / \mathrm{K}_{\mathrm{b}}\left(\varepsilon_{\mathrm{b}}-\varepsilon_{\mathrm{f}}\right)
$$

The apparent extinction coefficient $\varepsilon_{\mathrm{a}}$, was obtained by calculating $\mathrm{A}_{\mathrm{obs}} /$ [complex], $\varepsilon_{\mathrm{f}}$ and $\varepsilon_{\mathrm{b}}$ correspond to the extinction coefficient for the free (unbound) and fully bound complex respectively. A plot of [DNA] $/\left(\varepsilon_{\mathrm{a}}-\varepsilon_{\mathrm{f}}\right) v s$. [DNA] will have a slope equal to $1 /\left(\varepsilon_{\mathrm{b}}-\varepsilon_{\mathrm{f}}\right)$ and an intercept equal to $1 / K_{b}\left(\varepsilon_{b}-\varepsilon_{f}\right), K_{b}$ is then given by the ratio of the slope and the intercept.

\section{Results and Discussion}

ESR spectral studies of paramagnetic transition metal(II) complexes yield information about the distribution of the unpaired electrons and hence about the nature of the bonding between the metal ion and its ligands. There have been many reports concerning the applications of ESR to square -planar or distorted octahedral complexes of $\mathrm{Cu}(\mathrm{II})$ and of the interpretations of the ESR parameters in terms of covalency of the metal- ligand bonding ${ }^{9}$. The $\mathrm{Cu}(\mathrm{II})$ complexes exhibited well resolved anisotropic signals in the parallel and perpendicular regions as shown in Figures 1 and 2. The observed data (Table 1 ) showed that $g_{\Pi}=2.0-2.49$ and $g_{\perp}=2.09-2.24$.

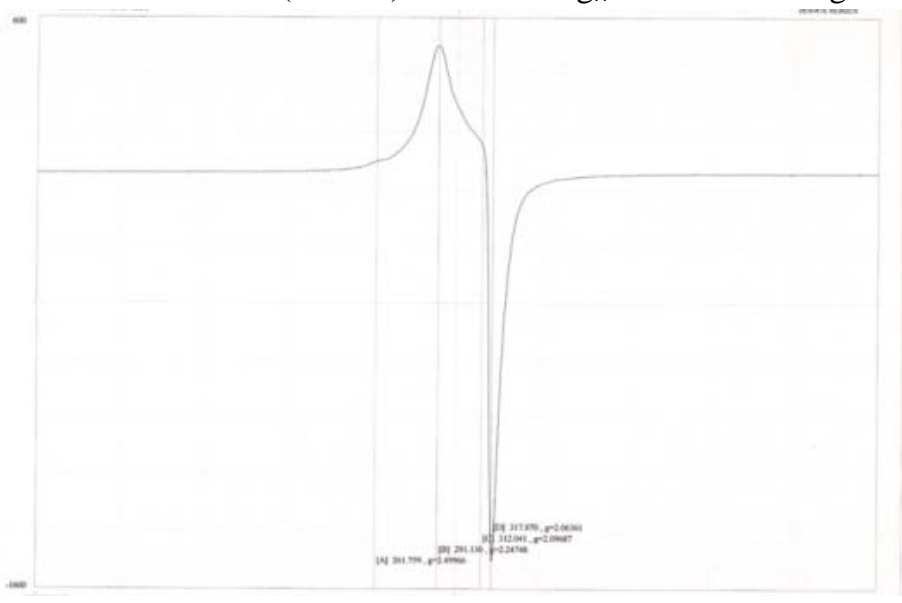

Figure 1. ESR spectrum of $\mathrm{Cu}(\mathrm{II})-5-\mathrm{Cl}$ SALAAP 


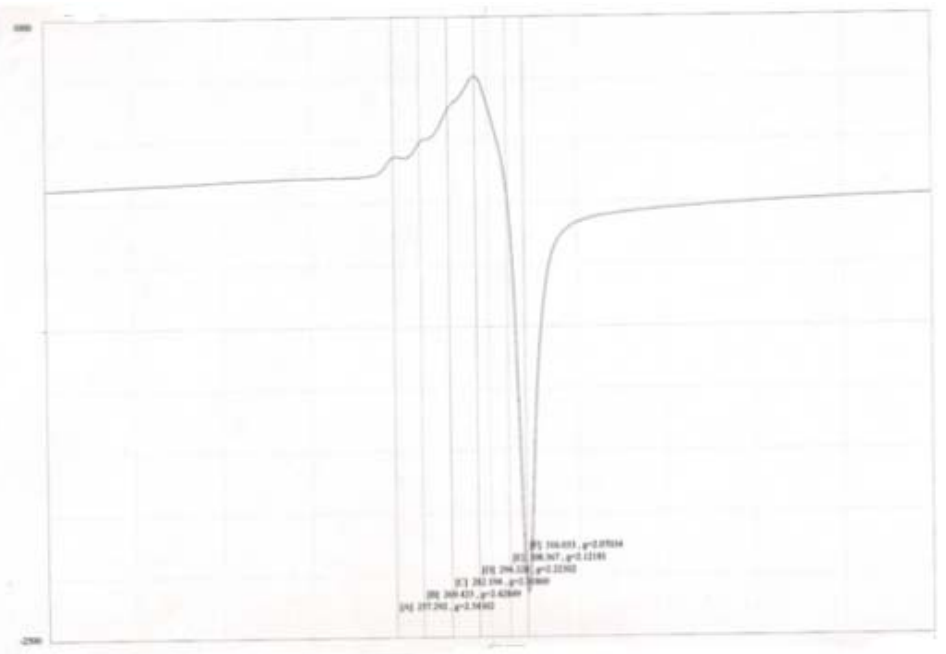

Figure 2. ESR spectrum of $\mathrm{Cu}(\mathrm{II})$-3-OEt SALAAP

Table 1. ESR parameters of $\mathrm{Cu}(\mathrm{II})$ complexes

\begin{tabular}{llllc}
\hline Complex & $\mathrm{g}_{\Pi}$ & $\mathrm{g}_{\perp}$ & $\mathrm{g}_{\mathrm{av}}$ & $\mathrm{G}$ \\
\hline $\mathrm{Cu}(\mathrm{II})-\mathrm{L}_{1}$ & 2.28 & 2.24 & 2.20 & 1.13 \\
$\mathrm{Cu}(\mathrm{II})-\mathrm{L}_{2}$ & 2.34 & 2.22 & 2.12 & 1.52 \\
\hline
\end{tabular}

The $g_{\Pi}$ values are greater than $g_{\perp}$ suggesting major distortion from octahedral symmetry in the $\mathrm{Cu}(\mathrm{II})$ complexes $^{10}$. The $\mathrm{g}_{\mathrm{II}}$ is a moderately sensitive function for indicating covalency. The $\mathrm{g}_{\Pi}>2.3$ is characteristic of anionic environment and $\mathrm{g}_{\Pi}<2.3$ is of covalent environment in $\mathrm{M}-\mathrm{L}$ bonding ${ }^{11}$. The observed $\mathrm{g}_{\Pi}$ values for the $\mathrm{Cu}(\mathrm{II})-5-\mathrm{Cl}$ SALAAP complex is less than 2.3, in agreement with the covalent character of the M-L bond. While $\mathrm{Cu}(\mathrm{II})-3-\mathrm{OEt}$ SALAAP complex showed $g_{\Pi}>2.3$, which is characteristic of anion environment. The trend $\mathrm{g}_{\Pi}>\mathrm{g}_{\perp}>2.0023$ observed for the complexes indicates that unpaired electron is localised in $\mathrm{d}_{\mathrm{x}-\mathrm{y}}^{2}{ }^{2}$ orbital of the $\mathrm{Cu}(\mathrm{II})$ ion. Thus a tetragonal geometry is proposed for the complexes ${ }^{12}$. Axial symmetry parameter $G=\left(g_{\Pi}-2\right) /\left(g_{\perp}-2\right)$, which measure the exchange interaction between the metal centres in a polycrystalline solid has been calculated, if $\mathrm{G}>4$ the exchange interaction is negligible and if $\mathrm{G}<4$ indicates considerable exchange interaction in the solid complexes $^{13}$.

The above reported complexes showed $\mathrm{G}$ values $<4$ indicating the exchange interaction in complexes. Earlier works reported ${ }^{14}$ that $\mathrm{g}_{\Pi}$ is 2.4 for copper-oxygen bonds and 2.3 for copper -nitrogen bonds. For these complexes, $g_{\Pi}$ values between 2.3-2.4 which further confirms the presence of copper- nitrogen and copper -oxygen bonds in these chelate complexes.

In general, complexes with aromatic moieties which bind to DNA through intercalation usually results in hypochromism and bathochromism due to the stacking interaction between aromatic chromophore of the complexes and the base pairs of DNA. The absorption spectra of the complexes, Ni(II)-5-Cl SALAAP (1), Co(II)-5-Cl SALAAP (2), Cu(II)-3-OEt SALAAP (3), in the absence and presence of calf thymus DNA are illustrated in Figures 35. In the presence of DNA, decrease of peak intensities were observed in the absorption spectra of complexes. 


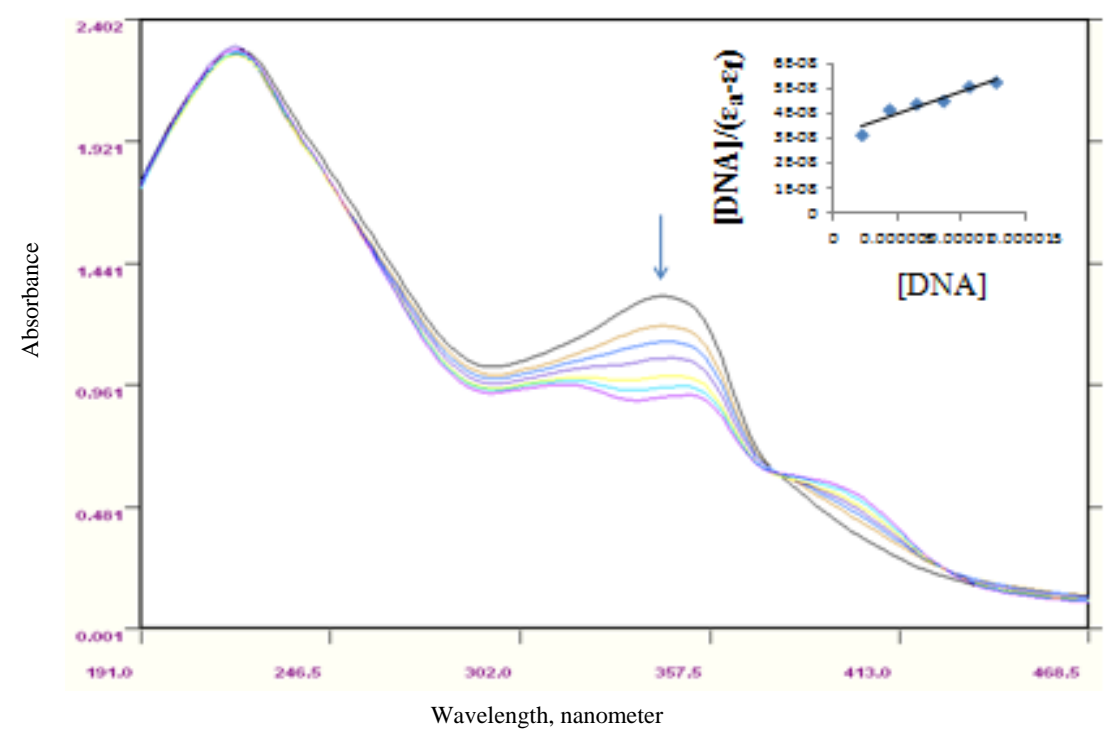

Figure 3. Absorption spectrum of complex $\left[\mathrm{Ni}(\mathrm{II})(5-\mathrm{Cl}-\mathrm{SALAAP})_{2}\right]$ in Tris $\mathrm{HCl}$ buffer at $25{ }^{0} \mathrm{C}$ in the presence of increasing amounts of DNA. Conditions: [Ni] $=16 \mu \mathrm{M}$. [DNA] $=0-140 \mu \mathrm{M}$. The arrow indicates the change in absorbance upon increasing the DNA concentration. Insert: Plot of [DNA]/( $\left.\varepsilon_{a}-\varepsilon_{f}\right) v s$. [DNA]

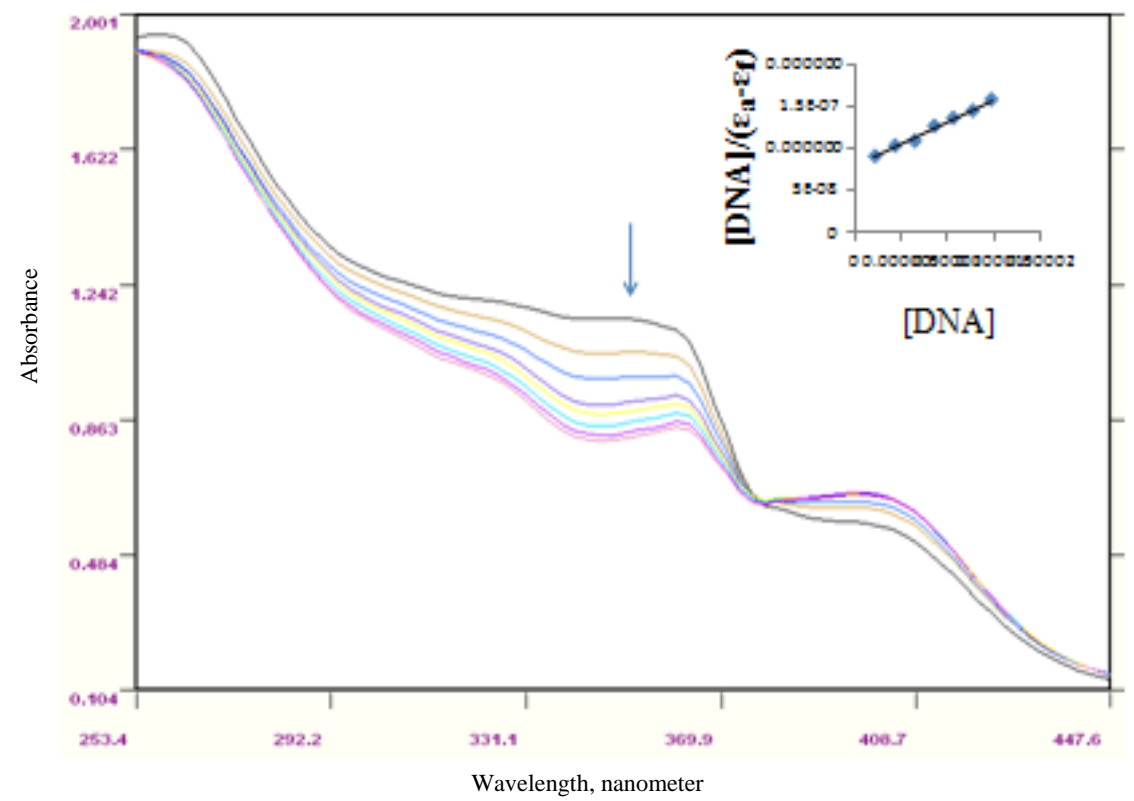

Figure 4. Absorption spectrum of complex [Co(II)(5-Cl-SALAAP) $\left.)_{2}\right]$ in Tris $\mathrm{HCl}$ buffer at $25{ }^{0} \mathrm{C}$ in the presence of increasing amounts of DNA. Conditions: [Co] $=16 \mu \mathrm{M}$, [DNA] $=0-140 \mu \mathrm{M}$. The arrow indicates the change in absorbance upon increasing the DNA concentration. Insert: Plot of [DNA]/( $\left.\varepsilon_{\mathrm{a}}-\varepsilon_{\mathrm{f}}\right) v s$. [DNA] 


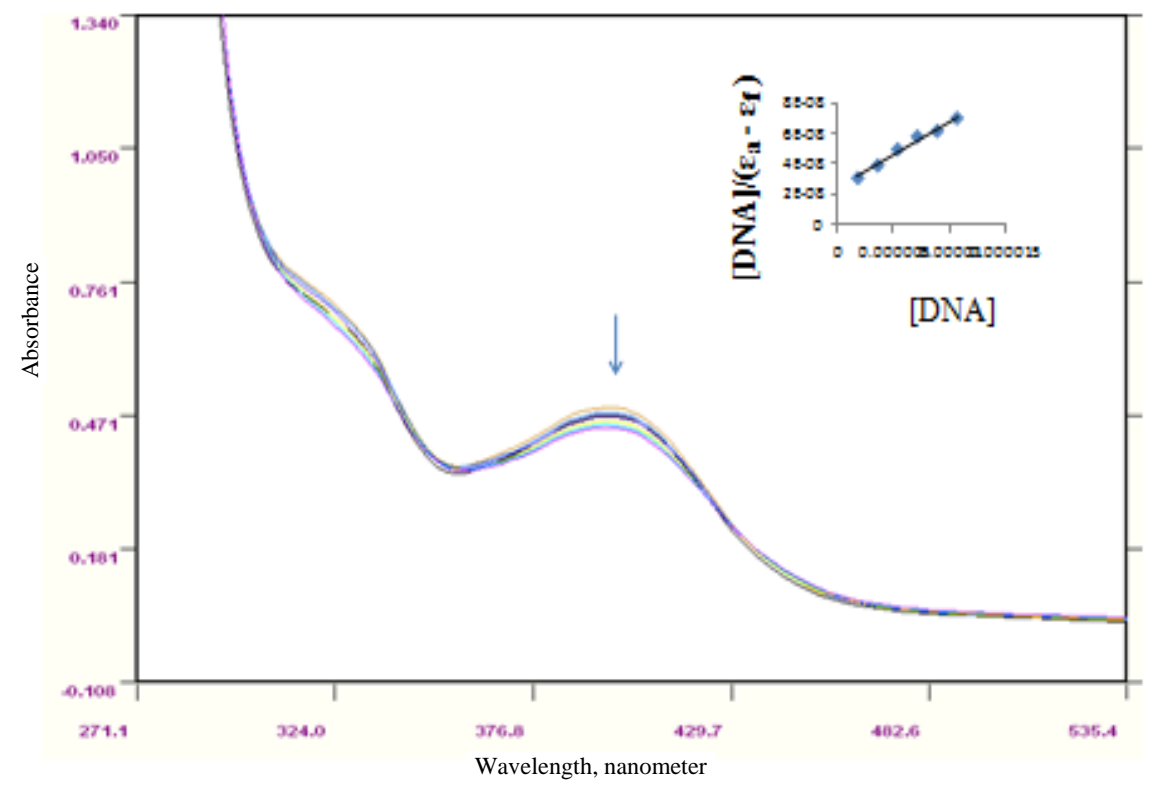

Figure 5. Absorption spectrum of complex [Cu(II)(3-OEt-SALAAP) $)_{2}$ in Tris $\mathrm{HCl}$ buffer at $25{ }^{0} \mathrm{C}$ in the presence of increasing amounts of DNA. Conditions: [Cu] $=16 \mu \mathrm{M}$, [DNA] $=$ 0-140 $\mu \mathrm{M}$. The arrow indicates the change in absorbance upon increasing the DNA concentration. Insert: Plot of [DNA]/( $\left.\varepsilon_{\mathrm{a}}-\varepsilon_{\mathrm{f}}\right) v s$. [DNA]

Hypochromism was suggested to be due to the interaction between the electronic state of the intercalating chromophore and that of the DNA bases ${ }^{15-19}$. In addition to the decrease in intensity, a small red shift (bathochromism) was also observed in the spectra. These spectral changes are consistent with the intercalation of complexes into the DNA base stack. The plot of the absorption titration data according to equation 1 gave a linear plot and resulted in an intrinsic binding constant $\left(\mathrm{K}_{\mathrm{b}}\right)$ of $3.3 \times 10^{4} \mathrm{M}^{-1}$ for complex $1,6.25 \times 10^{4} \mathrm{M}^{-1}$ for complex 2 and $2 \times 10^{5} \mathrm{M}^{-1}$ for complex 3 . The binding constants $\left(\mathrm{K}_{\mathrm{b}}\right)$ of different complexes are given in Table 2.

Table 2. DNA binding constants $\left(\mathrm{K}_{\mathrm{b}}\right)$ of metal complexes

\begin{tabular}{clc}
\hline S.No. & \multicolumn{1}{c}{ Compound } & $\mathrm{K}_{\mathrm{b}}, \mathrm{M}^{-1}$ \\
\hline 1 & $\mathrm{Ni}(\mathrm{II})$-5-Cl SALAAP & $3.3 \times 10^{4}$ \\
2 & $\mathrm{Co}(\mathrm{II})-5-$ Cl SALAAP & $6.25 \times 10^{4}$ \\
3 & $\mathrm{Cu}(\mathrm{II})-3-O E t$ SALAAP & $2 \times 10^{5}$ \\
\hline
\end{tabular}

\section{References}

1. Garnovskii A D, Vasilchenko O S, Garnovskii D A and Kharisov B I, J Coord Chem., 2009, 62(2), 151-204.

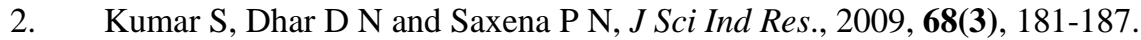

3. Raman N, Jeyamurugan R, Subbulakshmi M, Raja B and Yuvarajan Ramakrishnan Ch, Chem Papers, 2010, 64(3), 318-328.

4. Anupama.B, Mounika K, Sunitha M ,Gyana Kumari C and Vankata Ramana Reddy Ch, J Indian Chem Soc., 2012, 89(6),735-743. 
5. $\quad$ Murmer J, J Mol Biol., 1961, 3, 208.

6. Reichmann M E, Rice S A, Thomson C A and Dohi P, J Am Chem Soc., 1954, 76, 3047.

7. Kumar C V and Asuncion E H, J Am Chem Soc., 1993, 115, 8547.

8. Wolfe A, Shimer G H and Meehan T, Biochem., 1987, 26, 6392-6396.

9. Raman N, Thangaraja Ch and Johnsonraja S, Cental Eur J Chem., 2005, 3(3), 537-555.

10. Choi S N, Menzel E R and Wasson J R, J Inorg Nucl Chem., 1977, 39, 417-422.

11. Kumar D N, Singh B K, Garg B S and Singh P K, Spec Chim Acta, 2003, A59, 1487.

12. Raman N, Kulandaisamy A and Jeyasubramanian K, Synth React Inorg Nano-Met Org Chem., 2002, 32(9), 1583-1610.

13. Hathway B J, Bardley G N and Gillard R D, Eds., Essays in Chemistry, Academic press, Newyork, USA, 1971.

14. Sureh Babu V, Ramesh A, Raghuram P and Raghava Naidu R, Polyhedron, 1997, 6, 607.

15. Long E C and Barton J K, Acc Chem Res., 1990, 23, 271-273.

16. Dougherty G and Pigram W J, Crit Rev Biochem., 1982, 12, 103-141.

17. Berman H M and Young P R, Annu Rev Biophys Bioeng., 1981, 10, 87-114.

18. Cantor C and Schimmel P R and Freeman W H, San Francisco., Biophysical Chem., 1980, 2, 398.

19. Tysoc T A, Baker A D and Strekas T C, J Phy Chem., 1993, 97(2), 1707. 